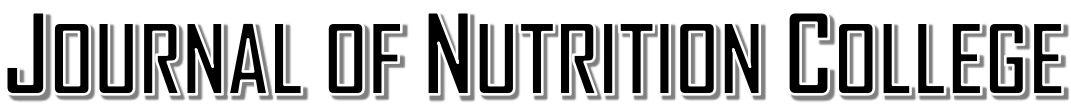

Volume 6, Nomor 4, Tahun 2017, Halaman 326-332

Online di : http://ejournal-s1.undip.ac.id/index.php/jnc

\section{HUBUNGAN DENSITAS ENERGI DAN ASUPAN CAIRAN DENGAN BERAT JENIS URIN PADA REMAJA}

\author{
Liani Setyarsih ${ }^{1}$, Martha Ardiaria ${ }^{1}$, Deny Yudi Fitranti ${ }^{1}$ \\ ${ }^{1}$ Departemen Ilmu Gizi Fakultas Kedokteran Universitas Diponegoro \\ Jln. Prof. H. Soedarto, SH., Semarang, Telp (024) 8453708, Email : gizifk@ undip.ac.id
}

\begin{abstract}
Background: Hydration status is a condition that describes total body fluid. One of the method of measuring hydration status is urine specific gravity. Energy density of food is the amount energy content of total weight food. Foods with high energy density tend to have a lower water content, which will affect fluid intake. The aim of this research was to know the correlation of energy density and fluid intake with urine specific gravity as one of the markers of hydration status. Method: This was an observational research with cross-sectional study design. The research was conducted in Senior High School 15 Semarang involving 55 subjects by Simple Random Sampling method. Food intake and fluid intake were assessed by 1x24 hours Food Recall. Urine specific gravity measured in laboratory. Body fat percentage measured by BIA (Bioelectrical Impendance Analysis) and physical activity assessed by $1 \times 24$ hours record physical activity. Data were analyzed by rank spearman.

Result: Median of urine specific gravity men and women was $1,02 \mathrm{~g} / \mathrm{ml}$. Mean of energy density in men was $1,8 \pm 0,32$

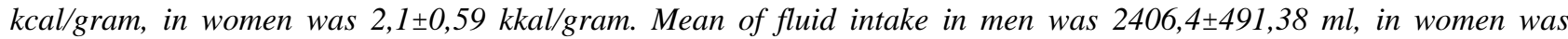
$2159,5 \pm 648,42 \mathrm{ml}$. There was significant correlation of fluid intake with hydration status $(p=0,027)$. There was no significant correlation of energy density and hydration status $(p=0,218)$. Multivariate analysis showed that 14,6\% of hydration status is affected by both fluid intake and energy intake.
\end{abstract}

Conclusion: There was significant correlation of fluid intake with urine specific gravity. There was no significant correlation of energy density and urine specific gravity.

Key Words: Energy density, fluid intake, urine specific gravity, hydration status, adolescents

\begin{abstract}
ABSTRAK
Latar Belakang: Status hidrasi merupakan suatu kondisi yang menggambarkan jumlah cairan dalam tubuh. Salah satu metode pengukuran status hidrasi adalah berat jenis urin. Makanan memiliki densitas energi, yaitu jumlah kandungan energi dari berat total suatu makanan. Makanan dengan densitas energi tinggi memiliki kandungan air yang rendah, sehingga akan mempengaruhi asupan cairan tubuh. Penelitian ini bertujuan untuk mengetahui hubungan densitas energi dan asupan cairan dengan berat jenis urin sebagai salah satu penanda status hidrasi.

Metode: Penelitian ini merupakan penelitian observasional dengan rancangan cross sectional. Penelitian dilaksanakan di SMA Negeri 15 Semarang. Jumlah subjek sebanyak 55 remaja dengan metode pengambilan sampel Simple Random Sampling. Data asupan diperoleh melalui Food Recall 1x24 jam. Pengukuran berat jenis urin dilakukan di laboratorium. Persen lemak tubuh diperoleh melalui pengukuran menggunakan BIA (Bioelectrical Impendance Analysis) dan aktivitas fisik menggunakan form record aktivitas fisik 1x24 jam. Data dianalisis menggunakan uji korelasi rank spearman.

Hasil: Median berat jenis urin laki-laki dan perempuan yaitu 1,02 $\mathrm{g} / \mathrm{ml}$. Rerata densitas energi laki-laki 1,8 $\pm 0,32$

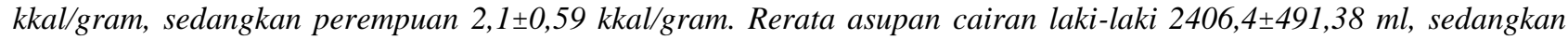
perempuan 2159,5 $\pm 648,42 \mathrm{ml}$. Terdapat hubungan yang bermakna antara asupan cairan dengan berat jenis urin $(p=0,027)$. Tidak terdapat hubungan yang bermakna antara densitas energi dengan berat jenis urin $(p=0,218)$. Analisis multivariat menunjukkan 14,6\% status hidrasi dipengaruhi oleh asupan cairan dan asupan energi.
\end{abstract}

Simpulan: Terdapat hubungan antara asupan cairan dengan berat jenis urin. Tidak terdapat hubungan antara densitas energi dan berat jenis urin.

Kata Kunci: Densitas Energi, Asupan Cairan, Berat Jenis Urin, Status Hidrasi, Remaja

\section{PENDAHULUAN}

Status hidrasi merupakan suatu kondisi yang menggambarkan jumlah cairan dalam tubuh seseorang. Keseimbangan cairan tubuh tercapai apabila volume air yang masuk ke dalam tubuh sama dengan volume air yang keluar. Air yang masuk ke dalam tubuh diperoleh dari makanan dan minuman. Air dikeluarkan dari tubuh melalui urin, keringat, pernapasan, dan feses. Apabila cairan dalam tubuh tidak seimbang maka akan terjadi dehidrasi.
Dehidrasi merupakan suatu kondisi dimana cairan yang hilang jumlahnya lebih banyak dibandingkan cairan yang masuk. ${ }^{1,2}$

Salah satu metode pengukuran status hidrasi yaitu menggunakan berat jenis urin. ${ }^{3}$ Berat jenis urin merupakan gambaran konsentrasi zat terlarut dalam urin, yaitu perbandingan antara massa larutan dengan volume air. ${ }^{4}$ Konsentrasi urin ditentukan oleh jumlah partikel seperti elektrolit, fosfat, urea, asam urat, protein, glukosa per volume urin. ${ }^{5}$ Seseorang yang 
mengalami dehidrasi akan meningkatkan reabsorpsi air oleh ginjal dan akan meningkatkan konsentrasi urin. ${ }^{4}$ Air memiliki berat jenis 1,000 dan akan selalu naik apabila ditambahkan zat terlarut ke dalamnya. Semakin terkonsentrasi urin makan berat jenis urin akan semakin meningkat. ${ }^{6}$

Masa remaja merupakan periode transisi antara anak-anak menuju dewasa. ${ }^{3}$ Remaja cenderung melakukan banyak aktivitas fisik dalam kegiatan sehari-hari, namun terkadang mereka tidak memperhatikan sinyal fisiologis terkait kehilangan cairan tubuhnya, seperti berkeringat yang berlebih dan timbulnya rasa haus. Hal tersebut menyebabkan mereka rentan mengalami dehidrasi karena mengabaikan tanda dan gejala tersebut. ${ }^{7}$ Hasil penelitian The Indonesian Regional Hydration Study (THIRST) di beberapa kota di Indonesia, pada tahun 2010 sebesar 46,6\% penduduk Indonesia mengalami dehidrasi ringan, jumlah tersebut lebih tinggi pada remaja $(49,5 \%)$ dibanding orang dewasa $(42,5 \%) .{ }^{8}$

Terdapat beberapa faktor yang mempengaruhi status hidrasi, seperti asupan cairan dan asupan makan. Kurangnya asupan cairan menyebabkan seseorang rentan mengalami dehidrasi. Hal tersebut karena cairan dalam tubuh akan berperan dalam proses metabolisme dan akan keluar dari tubuh bersama zat sisa metabolisme. Penelitian yang dilakukan di Bogor menyebutkan bahwa salah satu faktor yang mempengaruhi status hidrasi pada remaja adalah asupan cairan karena hasil penelitian tersebut menunjukkan terdapat hubungan antara tingkat asupan cairan dengan status hidrasi pada remaja. ${ }^{9}$

Faktor lain yang mempengaruhi status hidrasi yaitu asupan makan. Hal tersebut karena makanan yang dikonsumsi juga mengandung air sehingga berpengaruh pada keseimbangan cairan dalam tubuh. Penelitian yang dilakukan di Jerman menyebutkan bahwa terdapat hubungan antara status hidrasi dan profil diet pada anak-anak. Hasilnya menunjukkan bahwa profil diet berkorelasi dengan FWR (Free Water Reserve) yang merupakan salah satu penanda status hidrasi tubuh, namun hubungan yang paling signifikan ditunjukkan oleh densitas energi, yaitu asupan dengan densitas energi yang tinggi menunjukkan nilai FWR yang rendah sehingga meningkatkan risiko dehidrasi. ${ }^{10}$

Densitas energi adalah jumlah kandungan energi dari berat total suatu makanan. ${ }^{11,12}$ Makanan dengan densitas energi tinggi biasanya tinggi kandungan karbohidrat sederhana yang ditambah gula dan lemak, sehingga cenderung lezat, murah, dan banyak disukai termasuk oleh remaja. ${ }^{13}$ Makanan dengan densitas energi tinggi cenderung memiliki kandungan air yang rendah, sehingga akan mempengaruhi asupan cairan tubuh dan status hidrasi seseorang. ${ }^{14,15}$ Berdasarkan latar belakang tersebut, maka tujuan penelitian ini adalah untuk menganalisis hubungan densitas energi dan asupan cairan dengan berat jenis urin sebagai salah satu penanda status hidrasi pada remaja.

\section{METODE}

Penelitian ini merupakan penelitian observasional dengan rancangan cross sectional dan termasuk lingkup gizi masyarakat. Penelitian dilaksanakan di SMA Negeri 15 Semarang pada bulan Mei 2017. Jumlah subjek dalam penelitian ini yaitu 55 subjek. Metode pengambilan sampel menggunakan Simple Random Sampling. Kriteria inklusi sampel yakni remaja berusia 15-17 tahun, tidak sedang menjalani diet khusus atau diet karena penyakit tertentu, tidak mengalami diare dan muntahmuntah, tidak menderita penyakit ginjal dan diabetes mellitus, tidak mengonsumsi obat yang bersifat diuretik, serta bagi subjek perempuan tidak sedang mengalami menstruasi.

Data yang dikumpulkan dalam penelitian ini adalah karakteristik subjek, persen lemak tubuh, asupan makan, asupan cairan, berat jenis urin, serta aktivitas fisik. Aktivitas fisik diperoleh melalui formulir record aktivitas dalam sehari dengan durasi kegiatan per lima menit. Energi yang dikeluarkan untuk beraktivitas selama 24 jam dihitung menggunakan rumus 3,5 x BB x 5/1000 x Kelipatan EMB x W, dimana kelipatan EMB adalah kelipatan energi metabolisme basal masing-masing aktivitas dan $\mathrm{W}$ adalah waktu. ${ }^{16}$ Aktivitas fisik pada laki-laki dikategorikan menjadi ringan apabila $\leq 2600 \mathrm{kkal}$, sedang 2601-3400 kkal, dan berat 3401-3500 kkal. Sedangkan pada perempuan dikategorikan ringan apabila $\leq 2000 \mathrm{kkal}$, sedang 2001-2400 kkal, dan berat 2401-2600 kkal. ${ }^{17}$ Persen lemak tubuh diukur menggunakan Bioelectrical Impedance Analysis (BIA). Kategori persen lemak tubuh laki-laki dikatakan underfat apabila $\leq 10 \%$, normal $11-20 \%$, overfat $21-25 \%$, dan obese $26-35 \%$. Sedangkan pada perempuan dikategorikan underfat apabila persen lemak tubuh $\leq 15 \%$, normal $16-29 \%$, overfat $30-34 \%$, dan obese apabila $>35 \% .^{18}$

Asupan makan diteliti untuk mengetahui asupan energi dan densitas energi makanan yang dikonsumsi subjek melalui food recall selama $1 \times 24$ jam. Asupan energi dikategorikan tinggi apabila $>110 \%$ AKG, baik apabila 80-110\% AKG dan kurang apabil $<80 \%$ AKG. ${ }^{19}$ Perhitungan densitas energi makanan diperoleh melalui total energi makanan sehari dibagi berat makanan. Densitas energi dikategorikan menjadi empat yaitu densitas energi sangat rendah $0-0,6 \mathrm{kkal} / \mathrm{g}$, rendah $0,6-1,5$ $\mathrm{kkal} / \mathrm{g}$, sedang 1,5-4,0 kkal/g, dan tinggi 4,0-9,0 $\mathrm{kkal} / \mathrm{g} .{ }^{20}$ 
Asupan cairan adalah cairan yang masuk dalam tubuh yang berasal dari minuman dan makanan. Total asupan cairan diperoleh dari asupan air putih maupun minuman lainnya, serta cairan dari makanan yang diperoleh melalui dietary recall selama $1 \times 24$ jam yang diambil satu hari sebelum pengambilan sampel urin. Perhitungan total asupan cairan menggunakan rumus pertambahan total cairan dari minuman dan total cairan dari makanan yang dilihat dari DKBM 2005. Asupan cairan dikategorikan menjadi dua yaitu kurang dan cukup. Asupan cairan pada laki-laki dikatakan cukup apabila $\geq 2200 \mathrm{ml}$ dan kurang apabila $<2200 \mathrm{ml}$. sedangkan pada perempuan dikatakan cukup apabila $\geq 2100 \mathrm{ml}$ dan kurang apabila $<2100$ $\mathrm{ml}^{21}$

Berat jenis urin digunakan untuk mengukur status hidrasi subjek. Metode berat jenis urin (BJU) dipilih karena mudah dilaksanakan, waktu analisis singkat, ketepatan baik, biaya terjangkau, portabilitas alat baik, dan rendahnya risiko bagi subjek. Pengambilan sampel urin menggunakan botol kaca bening. Pemeriksaan BJU dilakukan di laboratorium dengan menggunakan metode reagent strip. BJU dikategorikan menjadi empat, yaitu status hidrasi baik apabila nilai BJU <1.010, dehidrasi ringan apabila nilai BJU 1.010-1.020 dan dehidrasi sedang apabila nilai BJU 1.021-1.030, dehidrasi berat apabila nilai BJU $>1.030 .22$
Pengolahan dan analisis data dilakukan menggunakan program komputer. Analisis univariat digunakan untuk mendeskripsikan masing-masing variabel. Data diuji normalitasnya menggunakan uji Kolmogorov-Smirnov $\quad(\mathrm{n}>50) \quad$ dengan nilai kemaknaan $\mathrm{p}>0,05$. Analisis bivariat digunakan untuk mengetahui hubungan masing-masing variabel bebas dengan variabel terikat menggunakan uji korelasi Rank Spearman karena data berdistribusi tidak normal. Analisis multivariat digunakan untuk mengetahui variabel prediktor dari berat jenis urin menggunakan uji regresi linier ganda.

\section{HASIL \\ Karakteristik Subjek Penelitian}

Jumlah subjek penelitian ini sebanyak 55 orang yang terdiri dari 25 remaja laki-laki dan 30 remaja perempuan dengan rentang usia 15-17 tahun. Perempuan memiliki rerata persen lemak tubuh dan asupan dengan densitas energi yang lebih tinggi dibandingkan laki-laki. Sementara rerata asupan cairan lebih tinggi pada laki-laki dibandingkan perempuan. Terdapat perbedaan yang signifikan antara persen lemak tubuh, aktivitas fisik, densitas energi antara laki-laki dan perempuan. Sedangkan berat jenis urin, asupan cairan, dan asupan energi antara laki-laki dan perempuan tidak ada perbedaan. Karakteristik subjek selengkapnya dapat dilihat pada Tabel 1.

Tabel 1. Karakteristik usia, persen lemak tubuh, aktivitas fisik, berat jenis urin, asupan cairan, densitas energi, dan asupan energi berdasarkan jenis kelamin

\begin{tabular}{|c|c|c|c|c|c|c|c|}
\hline \multirow{2}{*}{$\begin{array}{l}\text { Karakteristik } \\
\text { Subjek }\end{array}$} & \multicolumn{3}{|c|}{ Laki-laki $(\mathrm{n}=25)$} & \multicolumn{3}{|c|}{ Perempuan $(\mathrm{n}=30)$} & \multirow{2}{*}{$p$} \\
\hline & Minimal & Maksimal & Rerata/Median & Minimal & Maksimal & Rerata/Median & \\
\hline Usia (tahun) & 15 & 17 & $16^{\mathrm{b}}$ & 15 & 17 & $16^{\mathrm{b}}$ & $0,895^{\mathrm{c}}$ \\
\hline $\begin{array}{l}\text { Persen } \\
\text { lemak tubuh } \\
(\%)\end{array}$ & 7,8 & 39 & $18,6 \pm 8,07^{\mathrm{a}}$ & 13,7 & 38 & $25,8 \pm 7,02^{\mathrm{a}}$ & $0,001^{\mathrm{d} *}$ \\
\hline $\begin{array}{l}\text { Aktivitas } \\
\text { Fisik (kkal) }\end{array}$ & 2209,3 & 2973,1 & $2683,7 \pm 162,32^{\mathrm{a}}$ & 1796,9 & 2398 & $2190,23^{\mathrm{b}}$ & $0,001^{\mathrm{c} *}$ \\
\hline $\begin{array}{l}\text { Berat Jenis } \\
\text { Urin }\end{array}$ & 1,005 & 1,02 & $1,02^{\mathrm{b}}$ & 1,005 & 1,02 & $1,02^{\mathrm{b}}$ & $0,429^{c}$ \\
\hline $\begin{array}{l}\text { Asupan } \\
\text { Cairan (ml) }\end{array}$ & 1537,6 & 3391,9 & $2406,4 \pm 491,38^{\mathrm{a}}$ & 1162,49 & 4204,4 & $2159,5 \pm 648,42^{\mathrm{a}}$ & $0,123^{d}$ \\
\hline $\begin{array}{l}\text { Densitas } \\
\text { Energi } \\
(\mathrm{kkal} / \mathrm{g}) \\
\end{array}$ & 1,27 & 2,5 & $1,8 \pm 0,32^{\mathrm{a}}$ & 1,03 & 3,26 & $2,1 \pm 0,59^{\mathrm{a}}$ & $0,023^{\mathrm{d} *}$ \\
\hline $\begin{array}{l}\text { Asupan } \\
\text { Energi (kkal) }\end{array}$ & 1011,1 & 2627,5 & $1443,1^{b}$ & 757,1 & 1954,2 & $1213,9^{\mathrm{b}}$ & $0,056^{\mathrm{c}}$ \\
\hline
\end{tabular}

${ }^{\mathrm{a}}$ Rerata $\pm \mathrm{SD},{ }^{\mathrm{b}}$ Median

'Uji Mann-Whitney, ${ }^{\mathrm{d}} \mathrm{Uji} \mathrm{T}$ tidak berpasangan

*Perbedaan signifikan $(\mathrm{p}<0,05)$

Distribusi Frekuensi Densitas Energi, Asupan Energi, Asupan Cairan, Aktivitas Fisik, Persen Lemak Tubuh, dan Status Hidrasi

Subjek dalam penelitian ini memiliki berat jenis urin yang tergolong dalam kategori status hidrasi baik dan dehidrasi ringan. Sebanyak 29 $(52,8 \%)$ subjek memiliki status hidrasi baik yang terdiri dari 12 laki-laki dan 17 perempuan. Sedangkan dehidrasi ringan dialami oleh 26 subjek (47,2\%) yang terdiri dari 13 laki-laki dan 13 perempuan. 
Tabel 2. menunjukkan bahwa sebanyak 54,6\% subjek yang memiliki asupan dengan densitas energi tinggi mengalami dehidrasi ringan. Tidak ada subjek yang memiliki asupan energi tinggi, baik dari golongan dehidrasi ringan maupun status hidrasi baik. Subjek dengan asupan cairan kurang mengalami dehidrasi ringan sebanyak 65,2\%. Sebanyak 18 subjek (44\%) mengalami dehidrasi ringan pada kategori aktivitas fisik sedang. Subjek yang memiliki persen lemak tubuh pada kategori overfat sebanyak $54,5 \%$ mengalami dehidrasi ringan.

Tabel 2. Distribusi frekuensi densitas energi, asupan energi, asupan cairan, aktivitas fisik, dan persen lemak tubuh berdasarkan status hidrasi

\begin{tabular}{lcccccc}
\hline \multicolumn{1}{c}{ Karakteristik } & \multicolumn{2}{c}{ Status Hidrasi Baik } & \multicolumn{2}{c}{ Dehidrasi Ringan } & \multicolumn{2}{c}{ Total } \\
& $\mathrm{n}$ & $\%$ & $\mathrm{n}$ & $\%$ & $\mathrm{n}$ & $\%$ \\
\hline Densitas Energi & 4 & 57,1 & 3 & 42,9 & 7 & 12,7 \\
Rendah & 25 & 52,1 & 23 & 47,9 & 48 & 87,3 \\
Sedang & 29 & 52,8 & 26 & 47,2 & 55 & 100 \\
\hline Total & & & & & & \\
\hline Asupan Energi & 0 & 0 & 0 & 0 & 0 & 0 \\
Tinggi & 9 & 53 & 8 & 47 & 17 & 30,9 \\
Baik & 20 & 52,6 & 18 & 47,4 & 38 & 69,1 \\
Kurang & 29 & 52,8 & 26 & 47,2 & 55 & 100 \\
\hline Total & & & & & & \\
\hline Asupan Cairan & 21 & 65,6 & 11 & 34,4 & 32 & 58,2 \\
Cukup & 8 & 34,8 & 15 & 65,2 & 23 & 41,8 \\
Kurang & 29 & 52,8 & 26 & 47,2 & 55 & 100 \\
\hline Total & & & & & & \\
\hline Aktivitas Fisik & 23 & 56 & 18 & 44 & 41 & 74,5 \\
Sedang & 6 & 42,8 & 8 & 57,2 & 14 & 25,5 \\
Ringan & 29 & 52,8 & 26 & 47,2 & 55 & 100 \\
\hline Total & & & & & & \\
\hline Persen Lemak Tubuh & 4 & 57,1 & 3 & 42,9 & 7 & 12,7 \\
Underfat & 15 & 53,6 & 13 & 46,4 & 28 & 50,9 \\
Normal & 5 & 45,5 & 6 & 54,5 & 11 & 20 \\
Overfat & 5 & 55,5 & 4 & 44,5 & 9 & 16,4 \\
Obese & 29 & 52,8 & 26 & 47,2 & 55 & 100 \\
\hline Total & & & & & &
\end{tabular}

Hubungan antara densitas energi, asupan energi, asupan cairan, aktivitas fisik, dan persen lemak tubuh dengan berat jenis urin

Tabel 3. menunjukkan korelasi antara variabelvariabel yang diambil dengan berat jenis urin. Berdasarkan hasil analisis uji korelasi diketahui bahwa terdapat hubungan yang signifikan antara asupan cairan dengan berat jenis urin pada remaja $(\mathrm{p}<0,05)$ dan menunjukkan arah korelasi negatif $(\mathrm{r}=$ $0,315)$. Nilai $r$ negatif tersebut menunjukkan bahwa semakin tinggi konsumsi cairan, maka nilai berat jenis urin akan semakin rendah yang menunjukkan status hidrasi baik. Sedangkan variabel densitas energi, asupan energi, aktivitas fisik, dan persen lemak tubuh tidak menunjukkan adanya hubungan dengan berat jenis urin.

Tabel 3. Hubungan antara densitas energi, asupan energi, asupan cairan, aktivitas fisik, dan persen lemak tubuh dengan berat jenis urin

\begin{tabular}{lcc}
\hline \multirow{2}{*}{ Variabel } & \multicolumn{2}{c}{ Berat Jenis Urin } \\
\cline { 2 - 3 } & Koefisien Korelasi (r) & P value \\
\hline Densitas Energi & 0,164 & 0,232 \\
Asupan Energi & 0,158 & 0,250 \\
Asupan Cairan & $-0,315$ & $0,019^{*}$ \\
Aktivitas Fisik & 0,032 & 0,817 \\
Persen lemak tubuh & 0,077 & 0,578 \\
\hline
\end{tabular}

Uji korelasi rank spearman

*korelasi signifikan $(\mathrm{p}<0,05)$

Hasil analisis bivariat menunjukkan bahwa terdapat tiga variabel yang memiliki $\mathrm{p}<0,25$ antara lain densitas energi, asupan energi, dan asupan cairan.
Kemudian variabel-variabel tersebut dianalisis lebih lanjut menggunakan analisis regresi linier ganda untuk mengetahui variabel prediktor dari berat jenis 
urin. Hasil uji regresi linier ganda akan dinyatakan dalam Tabel 4.

Hasil analisis regresi linier ganda menunjukkan bahwa variabel asupan cairan dan asupan energi menjadi variabel prediktor dari berat jenis urin dengan nilai adjusted $R$ square yaitu 0,146 menunjukkan bahwa $14,6 \%$ variasi berat jenis urin dapat dijelaskan oleh variasi asupan cairan dan asupan energi.

Tabel 4. Hasil Uji Multivariat Asupan Cairan, Asupan Energi

\begin{tabular}{ccccc}
\hline Variabel & $\begin{array}{c}\text { Beta } \\
\text { (Standarized } \\
\text { Coefficients) }\end{array}$ & $\boldsymbol{p}$ & Konstanta & $\begin{array}{c}\text { Adjusted } \boldsymbol{R} \\
\text { Square }\end{array}$ \\
\hline Asupan Energi & 0,312 & 0,021 & 1,018 & 0,146 \\
Asupan Cairan & $-0,388$ & 0,005 & 1,18 & \\
\hline
\end{tabular}

\section{PEMBAHASAN}

Terdapat berbagai metode untuk mengukur status hidrasi, salah satunya adalah metode berat jenis urin. $^{3}$ Berat jenis urin merupakan gambaran konsentrasi zat terlarut dalam urin, yaitu perbandingan antara massa larutan dengan volume air di dalam urin. ${ }^{4}$ Beberapa penelitian menunjukkan bahwa parameter berat jenis urin memiliki tingkat konsistensi dan akurasi yang baik, sama seperti parameter osmolalitas urin. ${ }^{23}$ Metode berat jenis urin ini cocok digunakan pada penelitian terkait pengukuran status hidrasi dengan jumlah subjek yang besar. ${ }^{4}$

Berdasarkan hasil penelitian didapatkan sebanyak 47,2\% remaja mengalami dehidrasi ringan. Hal tersebut lebih tinggi daripada penelitian sebelumnya yaitu sebesar $44,5 \%$ remaja mengalami dehidrasi. ${ }^{9}$ Dehidrasi adalah kehilangan cairan tubuh yang berlebih karena penggantian cairan yang tidak cukup akibat asupan cairan yang tidak memenuhi kebutuhan tubuh ataupun karena peningkatan pengeluaran cairan baik melalui urin, keringat, dan proses pernapasan. ${ }^{24}$ Secara teori terdapat beberapa faktor yang menyebabkan dehidrasi seperti asupan cairan, aktivitas fisik, komposisi tubuh, jenis kelamin, suhu lingkungan. ${ }^{25}$ Hasil penelitian ini menunjukkan bahwa terdapat hubungan antara asupan cairan dengan berat jenis urin sebagai salah satu penanda status hidrasi. Hasil ini sejalan dengan penelitian sebelumnya yang menunjukkan adanya hubungan antara jumlah asupan cairan terhadap status hidrasi pada remaja di pesantren. ${ }^{26}$

Tubuh memperoleh cairan terutama dari konsumsi makanan dan minuman, serta sebagian kecil dari hasil metabolisme. ${ }^{27}$ Pada penelitian ini total asupan cairan diperoleh dari penjumlahan cairan yang berasal dari makanan dan minuman yang dikonsumsi. Hasilnya menunjukkan bahwa rerata asupan cairan laki-laki lebih tinggi dibandingkan perempuan. Studi di Jakarta dan Bandung menunjukkan hal yang sama, yaitu total asupan cairan laki-laki lebih besar (3591 ml) dibandingkan dengan perempuan $(2713 \mathrm{ml}){ }^{8}$ Hal ini sesuai dengan data
National Health And Nutrition Examination Survey (NHANES) III di USA yang menunjukkan rata-rata asupan total cairan pada remaja (14-18 tahun) lakilaki sebesar $3400 \mathrm{ml}$ per hari dan perempuan sebesar $2500 \mathrm{ml}$ per hari. ${ }^{28}$

Remaja saat ini sudah mengalami pergeseran pola makan dari pola makan tradisional ke pola makan barat. Pemilihan makanan tidak lagi didasarkan pada kandungan gizi, tetapi lebih banyak dipengaruhi oleh media massa dan sosialisasi antar teman sebaya. Remaja cenderung mengkonsumsi makanan dengan densitas energi tinggi yang biasanya tinggi kandungan karbohidrat sederhana, gula dan lemak. ${ }^{13}$ Hasil penelitian ini menunjukkan bahwa tidak terdapat hubungan antara densitas energi dengan berat jenis urin sebagai salah satu penanda status hidrasi ( $p$ value $=0,164$ ). Hal ini bertentangan dengan hasil penelitian sebelumnya yang menyebutkan bahwa terdapat hubungan antara status hidrasi dengan densitas energi, yaitu asupan dengan densitas energi yang tinggi dapat meningkatkan risiko dehidrasi. ${ }^{10}$ Meskipun pada penelitian ini tidak terdapat hubungan yang bermakna, namun arah korelasinya positif yang berarti semakin tinggi densitas energi maka semakin tinggi berat jenis urin.

Makanan memiliki densitas energi yaitu jumlah kalori per gram berat makanan yang dikonsumsi dan dihitung dengan cara membagi asupan energi total per hari (kkal) dengan berat makanan total yang dikonsumsi (gram). ${ }^{12,29}$ Makanan dengan densitas energi rendah mengandung kalori yang lebih rendah pula dan terdapat pada makanan dengan kandungan air tinggi, seperti sayur dan buah. Sedangkan makanan dengan densitas energi tinggi cenderung memiliki kandungan lemak yang tinggi dan kandungan air yang rendah, seperti biskuit, keju, dan mentega. ${ }^{14}$ Densitas energi sebagian besar dipengaruhi oleh kandungan lemak dan kandungan air dalam makanan. ${ }^{30}$ Air tidak mengandung energi ( 0 kkal) sehingga dapat menurunkan densitas energi makanan karena berpengaruh pada berat makanan bukan energi makanan. Sementara lemak mengandung energi paling tinggi $(9 \mathrm{kkal} / \mathrm{g})$ sehingga 
makanan tinggi kandungan lemak relatif memiliki densitas energi tinggi. ${ }^{15}$ Kandungan air yang terdapat dalam makanan akan mempengaruhi asupan cairan total sehingga akan mempengaruhi keseimbangan cairan tubuh dan status hidrasi.

Pada penelitian ini, rata-rata densitas energi makanan lebih tinggi pada perempuan $(2,1 \mathrm{kkalg} /)$ dibandingkan laki-laki $(1,8 \mathrm{kkal} / \mathrm{g})$. Hal tersebut sesuai dengan penelitian sebelumnya yang menunjukkan bahwa sebanyak $32,4 \%$ perempuan mengonsumsi makanan dengan densitas energi tinggi, sementara laki-laki hanya 5,9\%. ${ }^{31}$ Tingginya nilai densitas energi pada perempuan dikarenakan perempuan lebih banyak mengkonsumsi sumber makanan yang mengandung lemak seperti makanan yang digoreng, sedangkan konsumsi makanan pokok sumber karbohidrat seperti nasi lebih sedikit. Sedangkan pada laki-laki asupan makanan pokok seperti nasi cenderung lebih tinggi dibandingan makanan yang mengandung lemak seperti gorengan. Kelompok pangan pokok menyumbang cairan lebih banyak dibandingkan makanan yang banyak mengandung lemak, hal tersebut dapat mempengaruhi densitas energi makanan. ${ }^{14,32}$

Terdapat perbedaan persen lemak tubuh antara laki-laki dan perempuan $(p=0,001)$, yaitu persen lemak tubuh perempuan lebih tinggi dibandingkan laki-laki. Pada usia remaja terdapat perbedaan massa otot dan massa lemak antara perempuan dan laki-laki. Perempuan memiliki lebih banyak deposit lemak, sedangkan pada laki-laki terbentuk lebih banyak jaringan otot. ${ }^{33}$ Hasil penelitian ini menunjukkan bahwa persen lemak tubuh tidak berhubungan dengan berat jenis urin. Persen lemak tubuh memiliki pengaruh pada keseimbangan cairan dalam tubuh karena orang yang memiliki massa lemak lebih banyak maka air tubuh totalnya lebih rendah dibandingkan dengan orang yang massa lemak tubuhnya lebih sedikit. ${ }^{2}$ Meskipun dalam penelitian ini tidak terdapat hubungan yang bermakna antara persen lemak tubuh dengan berat jenis urin, tetapi dapat diketahui bahwa arah korelasi yang ditunjukkan adalah positif, yang berarti semakin tinggi persen lemak tubuh makan semakin tinggi berat jenis urin.

Pada penelitian ini, aktivitas fisik tidak berhubungan dengan berat jenis urin $(p>0,05)$. Hal tersebut sejalan dengan penelitian sebelumnya yang menunjukkan tidak adanya hubungan aktivitas fisik dengan status hidrasi. ${ }^{9,34}$ Kondisi tersebut dapat terjadi karena sebagian besar subjek $(79,31 \%)$ yang status hidrasinya baik memiliki aktivitas fisik dalam kategori sedang, dan sisanya dalam kategori ringan. Peningkatan aktivitas fisik dapat menyebabkan tubuh kehilangan cairan lebih banyak. Namun, kondisi tersebut dapat memicu pelepasan hormon yang dapat merangsang rasa haus untuk mengembalikan keseimbangan cairan tubuh. ${ }^{34}$

Hasil uji regresi linier ganda terhadap variabel bebas menunjukkan bahwa asupan cairan dan asupan energi memiliki pengaruh terhadap berat jenis urin. Variabel berat jenis urin digambarkan hanya sebesar $14,6 \%$ oleh variasi asupan cairan dan asupan energi. Asupan cairan dan asupan energi saling berhubungan, hal tersebut berkaitan dengan perhitungan kebutuhan cairan berdasarkan kebutuhan energi. ${ }^{35}$ Perhitungan kebutuhan energi yang dilakukan oleh ilmuwan dilakukan dengan metode yang akurat, digolongkan berdasarkan jenis kelamin dan kelompok usia, serta mempertimbangkan ukuran tubuh dan tingkat aktivitas fisik. $^{36}$ Kebutuhan cairan tubuh juga dipengaruhi oleh luas permukaan tubuh dan tingkat aktivitas fisik, serta berdasarkan jenis kelamin dan usia. $^{35}$ Oleh sebab itu, ilmuwan mengemukakan kebutuhan cairan yang berdasarkan kebutuhan energi, yaitu $1 \mathrm{ml} / \mathrm{kkal}^{37}$ Terdapat studi eksperimen mengenai asupan cairan dan asupan energi yang hasilnya menunjukkan bahwa pengurangan asupan cairan juga menyebabkan berkurangnya asupan energi yang disebabkan penurunan konsumsi karbohidrat dan protein. ${ }^{38} \mathrm{Hal}$ tersebut menunjukkan bahwa pengurangan asupan cairan yang akan mempengaruhi status hidrasi tubuh juga akan mempengaruhi asupan energi dan komposisi makronutrien. ${ }^{10}$

\section{SIMPULAN}

Penelitian ini membuktikan bahwa terdapat hubungan asupan cairan dengan berat jenis urin pada remaja $(p=0,027)$. Sementara densitas energi makanan tidak terbukti berhubungan dengan berat jenis urin $(p=0,232)$.

\section{SARAN}

Perlunya menjaga keseimbangan cairan tubuh agar tercapai status hidrasi yang baik pada remaja. Cara yang dapat dilakukan yaitu dengan mengonsumsi cairan yang cukup sesuai kebutuhan tubuh dan mengonsumsi makanan dengan densitas energi yang lebih rendah.

\section{DAFTAR PUSTAKA}

1. Yuniastuti A. Gizi dan Kesehatan. Yogyakarta: Graha Ilmu; 2008.

2. Santoso BI, Hardinsyah, Siregar P, Pardede SO. Air bagi Kesehatan. Jakarta: Centra Communications; 2011.

3. Mahan LK, Escott-Stump S. Krause's Food \& Nutrition Therapy. 12th ed. Canada: Saunders Elsevier; 2008. 246-259 p.

4. Baron S, Courbebaisse M, Lepicard EM, Friedlander G. Assessment of hydration status in a large population. Br J Nutr. 2015;113(1):147-58. 
5. Dolan MG. Best Practice for Clinical Hydration Measurement. Athl Ther Today. 2009;14(1):9-11.

6. Nelms M, Sucher KP, Lacey K, Roth SL. Nutrition Therapy \& Pathophysiology. 2nd ed. USA: Cengange Learning; 2010. 495-496 p.

7. Brown JE, Isaacs JS, Krinke UB, Lechtenberg E, Murtaugh MA. Nutrition Through the Life Cycle. 4th ed. USA: Cengange Learning; 2011.357-363 p.

8. Hardinsyah, Sriardiningsih, Razaktha, Briawan D, Effendi YH, Aries M, et al. Kebiasaan Minum dan Status Hidrasi pada Remaja dan Dewasa di Dua Wilayah Ekologi Berbeda. Indones Reg Hydration Study(THIRST). 2010;

9. Gustam, Hardinsyah, Briawan D. Faktor Risiko Dehidrasi pada Remaja dan Dewasa. Institut Pertanian Bogor; 2012.

10. Stahl A, Kroke A, Bolzenius K, Manz F. Relation between hydration status in children and their dietary profile-result from the DONALD study. Eur J Clin Nutr. 2007;61(12):1386-92.

11. Berdanier CD, Dwyer JT, Heber D. Handbook of Nutrition and Food. 3rd ed. London: CRC Press; 2014. 256 p.

12. Ledikwe JH, Blanck HM, Khan LK, Serdula MK, Seymour JD, Tohill BC, et al. Dietary Energy Density Determined by Eight Calculation Methods in a Nationally Representative United States Population. J Nutr. 2005;135(2):273-8.

13. Kant AK, Graubard BI. Energy density of diets reported by American adults: association with food group intake, nutrient intake, and body weight. Int $\mathbf{J}$ Obes. 2005;29(8):950-6.

14. Bottone FG. The Diet Denominator: A Practical Guide to Choosing Low Energy Density Foods. 2nd ed. Morrisville: Scriptorium Medica Medical Writing; 2010. 20-22 p.

15. Rolls BJ. The relationship between dietary energy density and energy intake. Physiol Behav [Internet]. 2009;97(5):609-15.

16. Guricci S. Gizi Olahraga dalam Gizi Olahraga, Sehat Bugar dan Berprestasi. Jakarta: Departeman Kesehatan RI; 1992.

17. Marsetyo, Kartasapoetra. Korelasi Gizi, Kesehatan dan Produktivitas Kerja. Jakarta: Rineka Cipta; 1995.

18. McCarthy HD, Cole TJ, Fry T, Jebb SA, Prentice AM. Body fat reference curves for children. Int $\mathbf{J}$ Obes. 2006;30(4):598-602.

19. Lembaga Ilmu Pengetahuan Indonesia. Widyakarya Nasional Pangan dan Gizi. Jakarta: LIPI; 2004.

20. Bean A. The Complete Guide to Strength Training. 4th ed. London: A \& C Black; 2008. 36 p.

21. Lembaga Ilmu Pengetahuan Indonesia. Widyakarya Nasional Pangan dan Gizi. Jakarta: LIPI; 2014.

22. Austin K, Seebohar B. Performance Nutrition: Applying the Science of Nutrient Timing. USA: Human Kinetics; 2011. 39 p.

23. Perrier E, Demazires A, Girard N, Pross N, Osbild D, Metzger D, et al. Circadian variation and responsiveness of hydration biomarkers to changes in daily water intake. Eur J Appl Physiol. 2013;113(8):2143-51.

24. Armstrong LE. Assessing hydration status: the elusive gold standard. J Am Coll Nutr. 2007;26(5):575S-584S.

25. Grandjean AC, Reimers KJ, Buyckx ME. Hydration: Issues for the $21 \mathrm{st}$ Century. Nutr Rev. 2003;61(8):261-71.

26. Ratnasari M. Hubungan Pola Minum dan Jumlah Konsumsi Cairan dari Minuman Terhadap Status Dehidrasi Usia 16-18 Tahun di Pondok Pesantren Darunnajah Jakarta Selatan Tahun 2012. Gizi Indones. 2012;35(2):120-5.

27. Thompson J, Manore M, Vaughan L. The Science of Nutrition. 2nd ed. San Fransisco: Pearson Benjamin Cummings; 2011. 323-349 p.

28. Kant AK, Graubard BI. Contributors of water intake in US children and adolescents: associations with dietary and meal characteristics--National Health and Nutrition Examination Survey 2005-2006. Am J Clin Nutr. 2010;92(4):887-96.

29. Centers for Disease Control and Prevention. LowEnergy-Dense Foods and Weight Management: Cutting Calories While Controlling Hunger. In Atlanta: CDC; 2008.

30. Bechthold A. Food Energy Density and Body Weight A scientific statement from the DGE. Ernaehrungs Umschau Int. 2014;61(1):2-11.

31. Dewi UP. Hubungan Antara Densitas Energi Dan Kualitas Diet Dengan Indeks Massa Tubuh (IMT) Pada Remaja. Universitas Diponegoro; 2013.

32. Grunwald GK, Seagle HM, Peters JC, Hill JO. Quantifying and separating the effects of macronutrient composition and non-macronutrients on energy density. Br J Nutr. 2001;86(2):265-76.

33. Heymsfield SB, Lohman TG, Wang Z, Going SB. Human Body Composition. 2nd ed. USA: Human Kinetics; 2005.

34. Mora-Rodriguez R, Ortega JF, Fernandez-Elias VE, Kapsokefalou M, Malisova O, Athanasatou A, et al. Influence of Physical Activity and Ambient Temperature on Hydration: The European Hydration Research Study (EHRS). Nutrients. 2016;8(5):1-13.

35. Popkin BM, D'Anci KE, Rosenberg IH. Water, hydration, and health. Nutr Rev. 2010;68(8):439-58.

36. Panel on Dietetic Products Nutrition and Allergies. Dietary reference values for water Scientific Opinion of the Panel on Dietetic Products, Nutrition and Allergies. EFSA J. 2009;8(3):1459.

37. National Research Council. Recommended Dietary Allowances. Washington DC: National Academy Press; 1989.

38. Shirreffs SM, Merson SJ, Fraser SM, Archer DT. The effects of fluid restriction on hydration status and subjective feelings in man. Br J Nutr. 2004;91(6):951-8. 